\title{
W świecie nazw. Księga jubileuszowa dedykowana Profesorowi Czesławowi Kosylowi, red. Halina Pelcowa, Wydawnictwo Uniwersytetu Marii Curie-Skłodowskiej, Lublin 2010, ss. 440
}

Onomastyka literacka i uzualna, teoria i metodologia onomastyki, historia języka polskiego i dialektologia, stylistyka i semantyka, pragmatyka językowa oraz glottodydaktyka to wielkie pasje naukowe Czesława Kosyla, które świadczą bezspornie o bogatym zakresie jego zainteresowań naukowych oraz o interdyscyplinarnym charakterze prowadzonych badan. W sześćdziesiątą piątą rocznicę urodzin oraz na czterdziestolecie pracy naukowej grono kolegów i wiernych przyjaciół ofiarowało Jubilatowi księgę artykułów, w których niejednokrotnie podkreślano rolę badacza w rozwoju językoznawstwa polonistycznego.

Recenzowana publikacja składa się z rozbudowanej części wstępnej oraz 37 artykułów autorstwa naukowców wywodzących się z różnych ośrodków uniwersyteckich nie tylko naszego kraju.

Tom otwiera słowo wstępne Haliny Pelcowej. W dalszej kolejności dokonano przedstawienia sylwetki Jubilata (J. Mazur, Z Kolonii Wojciechów w fascynujacy świat onomastyki - w czterdziestolecie działalności naukowej prof. dra hab. Czesława Kosyla), zamieszczono Wykaz prac naukowych Profesora Czesława Kosyla (I. Domaciuk-Czarny, A. Siwiec) oraz Wykaz prac doktorskich i magisterskich napisanych pod kierunkiem Profesora Czesława Kosyla (Izabela Domaciuk-Czarny).

Pierwszy z artykułów (Na drodze życia, czyli o semantyce drogi w przysłowiach polskich J. Adamowskiego) jest próbą zestawienia znaczeń leksemu droga odnotowanych w słownikach ogólnych oraz gwarowych języka polskiego, a także w rodzimych przysłowiach. Dokumentacja źródłowa semantyki drogi-choć zróżnicowana - unaocznia znaczenia implikujące jakiś wykładnik materialny, np. szlak komunikacyjny, ścieżkę, główny nurt rzeki, przedziałek 
we włosach. Polska paremiografia natomiast odnotowuje znaczenia, w których czytelne jest odwołanie do użytkownika obiektu. „Generalnie zatem droga w przysłowiach polskich jest zwykle podstawą do metaforycznego odniesienia i przedstawienia życia ludzkiego w jego zawiłych aspektach, ze szczególnym uwzględnieniem strony etycznej. Punktem wyjścia dla tej metaforyzacji są wszakże odwołania do wybranych cech obiektu, często zestawione w pary binarnych opozycji” (s. 33). Zatem leksem droga w polskich przysłowiach jest jednym z elementów ogólnego modelu doświadczania świata przez człowieka. Ma ponadto właściwości delimitacyjne horyzontalne (swój - obcy) oraz wertykalne (świat ludzi i rzeczywistość pozaziemska).

M. Biolik w artykule Z leksyki mazurskiej: czasownik gudać dokonała analizy czasownika gudać, który wystapił we fragmencie wiersza mazurskiego chłopa, ludowego poety, Jana Luśtycha. Badanego wyrazu nie notują ani współczesne, ani historyczne słowniki języka polskiego. Omawiany leksem poświadczony jest jedynie w polskiej gwarze na Mazurach i ma odpowiedniki (morfologiczne oraz leksykalne) w językach południowo- i wschodniosłowiańskich oraz w innych językach indoeuropejskich (np. w albańskim). Szczegółowa analiza etymologiczna leksemu doprowadziła do wniosku, że w wyrażeniu konie biczem gudać wyraz gudać znaczy „trącać, dotykać (batem) powoli, niezdarnie, opieszale łechcząc, łaskocząc (konie)” (s. 43).

Kolejny artykuł w recenzowanym tomie (B. Boniecka - Dziecięce fascynacje przyroda) jest swoistym studium przypadku. To próba weryfikacji prawdziwości sądów dziecka o rzeczywistości pozajęzykowej (świat zwierząt) oraz analiza wiedzy obu (rodzica i dziecka) komunikujących się osób. Autorka konkluduje: „W rozmowach dziecko poznaje zasady racjonalnego myślenia i odróżniania racjonalnych zachowań od fantazji. Irracjonalne zachowania są przedmiotem rozważań. Dziecku wyjaśnia się różnice między rzeczywistym a fantastycznym zdarzeniem, tłumaczy się sytuacje uzasadniające emocjonalność bądź intelektualność w postawie, czyni się to językiem naturalnym, ale niepozbawionym naukowego wymiaru" (s. 60).

W artykule zatytułowanym Imiona pochodzace od pojęcia życia 'vita' E. Breza omawia w porządku alfabetycznym kilkanaście imion utworzonych od tytułowego leksemu. Autor przedstawił etymologię następujących antroponimów: stp. Dobrożyźń, gr. Dzoe, hebr. Ewa, Ewita i podobnych, niem. Leberecht, łac. Witalis, Witalian, Wita, Witalia, Witalisa i podobnych oraz gr. Zozym i podobnych.

A. Cieślikowa w artykule Gniazda słowotwórcze tworzone od antroponimów dąży do ukazania poglądów na temat gniazd słowotwórczych konstytuowanych przez antroponimy, dzieli się swymi uwagami o interpretacji antroponimu stojącego na czele gniazda. Punktem wyjścia krytycznych rozważań stał 
się tekst autorstwa K. Kallas zatytułowany Struktura gniazd słowotwórczych konstytuowanych przez antroponimy. Cieślikowa konstatuje - powołując się na wcześniejsze ustalenia Czesława Kosyla - iż „na czele gniazda słowotwórczego odantroponimicznego stoi często «metaforyczny antroponim»" (s. 77).

Kolejny z artykułów (Formuly identyfikacyjne ludności południowego Podlasia (na podstawie inskrypcji nagrobnych pogranicza polsko-wschodniostowiańskiego) autorstwa F. Czyżewskiego) stanowi opis formuł użytych do nominacji osób. Materiał wyekscerpowano z inskrypcji nagrobnych cmentarza unickiego w Kostomłotach. Dalej poddano go analizie w celu odpowiedzi na pytanie o stopień zależności między konkretną praktyką nazewniczą a ówczesnym uzusem warunkowanym swoistymi cechami polsko-wschodniosłowiańskiego pogranicza.

Tekst autorstwa I. Domaciuk-Czarny - Nazewnictwo mikronacji w rzeczywistości wirtualnej (na przykładzie polskich stron internetowych) - jest niezwykle interesującym opisem kreacji onomastycznych dokonywanych przez twórców wirtualnych państw (tzw. mikronacji) na potrzeby zabawy internetowej. Badany onomastykon z jednej strony jest głęboko osadzony w autentycznej onimii świata realnego, $z$ drugiej zaś wskazuje na suwerenne akty nominacyjne kreatorów nazw wyrażane nazwami fantastycznymi.

W artykule Tradycja $w$ mechanizmach perswazyjnych reklamy D. Filar zwraca uwagę, że w tekstach reklamowych bardzo często używa się słów, które mają wyzwolić przychylne nastawienie odbiorców. Są to zazwyczaj wyrazy modne lub słowa klucze współczesnej reklamy. W tak skonstruowanych tekstach dominuje funkcja nakłaniająca i ekspresywna, jednak perswazja ukrywana jest za pozornie prymarną funkcją informacyjną. Analiza komunikatów reklamowych w recenzowanym tekście dotyczy tych reklam, które zawieraja słowo tradycja i jego pochodne. Autorka chce „Zwrócić uwagę na to, w jaki sposób nadawca «gra» pozytywnymi treściami konotacyjnymi, eksponując pewne elementy znaczenia słowa, przy jednoczesnej neutralizacji innych (często podstawowych) komponentów semantycznych" (s. 106). W konstatacji Filar stwierdza, że leksemem tradycja w wielu komercyjnych reklamach szafuje się w celu uruchomienia pożądanych skojarzeń pozytywnych.

S. Gala w niewielkim artykule Nazwiska polskie typu Kosyl dokonał onomastycznej analizy nazwiska Jubilata. Onim Kosyl jest derywatem antroponimicznym od prymarnej podstawy imiennej (hipoc. Kosz, Koś < Konstanty). „Mniej prawdopodobne wydaje się imię Kosma, choć wykluczyć się nie da. Nie można też wykluczyć apelatywu kos 'ptak z rodziny drozdów' (SW), który zgodnie z modelem 'jaki jest' mógł stać się protonazwiskiem, a następnie podstawą dla derywatu z wykładnikiem -yl, a także ap. kosz" (s. 119). Wykładnikiem nazwiskotwórczym jest historyczny sufiks $-i /-y l$ o raczej peryferyjnym 
charakterze, który nie jest zbyt produktywny także w obszarze leksyki apelatywnej (por. badyl, szczyl, motyl).

Celem artykułu zatytułowanego Rzeczownikowe attributiva $w$ gwarze Sarbic i Motyczna autorstwa R. Gliwy jest ,po pierwsze wskazanie mechanizmów i środków słowotwórczych, za pomocą których wyrażana jest atrybutywność, po drugie określenie, jaki udział wśród zanotowanych nazw maja formacje nacechowane ekspresywnie, po trzecie ustalenie, jaki jest stosunek atrybutywności do ekspresywności” (s. 123). Autorka precyzuje, co uznaje za nomina attributiva oraz podaje trzy wyznaczniki atrybutywności wyrazu (właściwe znaczenie semantyczne, znaczenie leksykalne wskazujące na atrybut oraz występowanie funkcji ekspresywnej). W podsumowaniu badaczka podkreśla, że zauważalna różnorodność formacji atrybutywnych jest wyznacznikiem potrzeby ekspresywnego nazwania członków danej społeczności. Objawia się to mnogością synonimów, a także tendencją do wyrażania atrybutywności nie tylko przez przymiotnik, lecz również przez formacje dewerbalne i odrzeczownikowe.

S. Grabias w artykule Język w procesie poznania $i$ w interakcji. Przestrzenie interakcyjne konfrontuje ze sobą dwa sposoby myślenia o języku. Jeden z nich przybiera formułę: język jest zjawiskiem społecznym, drugi zaś głosi, że język jest przyrodzony człowiekowi. Rozważając drugie stanowisko, autor dokonał opisu teorii interakcji. Głównym założeniem uczynił sąd, że proces nadawania znaczeń ,zachowaniom własnym i zachowaniom innych uczestników grupy społecznej w warunkach biologicznej i społecznej normy funkcjonowania człowieka dokonuje się poprzez język i tylko poprzez język" (s. 144). Na końcu badacz wyodrębnił dwie przestrzenie interakcyjne: 1. TERAZ, czyli interakcje ze współczesnymi uczestnikami życia społecznego oraz 2. PRZEDTEM i POTEM, czyli interakcje z byłymi i przyszłymi uczestnikami życia społecznego.

Tekst autorstwa E. Jakus-Borkowej - Modele nazewnicze w polskiej kosmonimii (Synteza) - jest próbą przedstawienia najistotniejszych wiadomości o strukturze i semantyce kosmonimów, czyli nazw własnych obiektów pozaziemskich. Podstawą materiałową badań są nomina propria opracowane już w monografii autorki (Polskie nazewnictwo kosmiczne, Opole 2004), czyli „1) główne składniki Kosmosu, takie jak: planety, ich księżyce, gwiazdozbiory, mgławice, galaktyki, planetoidy, różne gwiazdy, komety oraz roje z aktywnością meteorów, 2) «utwory» terenowe, czyli wyróżniające się ukształtowaniem formacje przestrzenne zauważone na niektórych planetach i ich satelitach, a także: 3) widziane z Ziemi gołym okiem gwiazdy i gwiazdozbiory, które w środowisku ludowym posiadają określenia gwarowe" (s. 157). Na potrzeby recenzowanego tekstu badaczka przyjęła klasyfikację nazw ze względu na 
ich rozpowszechnienie. Dlatego wyodrębnia kosmonimy globalne i lokalne. W podsumowaniu artykułu podkreśla natomiast, że onimy kosmiczne należą do zbioru otwartego, który stale się powiększa.

M. Juda w artykule $O$ potrzebie opracowania staropolskich wydań dziet Mikołaja Reja zwróciła uwagę na konieczność opisania istniejących już wydań dzieł pana z Nagłowic oraz ich właściwy układ chronologiczny. „Jak istotne znaczenie posiada takie postępowanie badawcze w bardziej dogłębnym poznaniu twórczości pisarza i określeniu jej miejsca w staropolskiej kulturze literackiej - i nie tylko - dowodzą tego typu badania przeprowadzone w kontekście dorobku Jana Kochanowskiego" (s. 173-174).

Kolejnym artykułem w recenzowanym tomie jest tekst Tytuly podręczników szkolnych zaproszeniem do lektury autorstwa M. Karwatowskiej. Badaczka zwraca uwagę, że niedawna reforma szkolnictwa wywołała lawinowy wzrost różnych inicjatyw wydawniczych, co szczególnie jest widoczne w wypadku podręczników. Ich autorzy, starając się zachęcić jak najliczniejsze grono odbiorców do kupna konkretnego podręcznika, nadają im wymyślne tytuły. Zazwyczaj antycypują one tekst. „Trudno bowiem wypowiadać się na temat konkretnego podręcznika po pobieżnej lekturze, a zapoznając się z określoną pozycją, nauczyciel nie ma czasu na jej gruntowną analizę. Tymczasem atrakcyjny, oryginalny, dynamiczny, a niekiedy zaskakujący tytuł często przesądza o zakupie tego środka dydaktycznego" (s. 183). Tytuły podręczników szkolnych ze wszystkich etapów nauczania poddała autorka oglądowi, wyróżniając w nich słowa kluczowe. Dla klas I-III szkoły podstawowej jest to leksem szkoła, dla klas IV-VI oraz gimnazjum - słowo i świat, a dla szkoły średniejrzeczownik człowiek. Tekst zakończyła badaczka uwagami o funkcji tytułów i spostrzeżeniami dotyczącymi struktur językowych uatrakcyjniających tytuły podręczników szkolnych.

Relacje historycznojęzykowe między leksemami biskup, episkop, władyka to tekst autorstwa J. Kościa. W artykule zostały omówione trzy leksemy religijne: biskup, episkop oraz władyka - używane jako nazwy najwyższych rangą dygnitarzy kościelnych. Należą one do najstarszej warstwy terminologii sakralnej, a ich źródłosłów jest grecki. Za pośrednictwem języka niemieckiego i języka czeskiego dotarły do polszczyzny leksemy biskup i episkop, władyka zaś jest ukrainizmem, kalką greckiego leksemu o znaczeniu 'pan; tytuł biskupa'. Z czasem „władyka, przyjmując nowy komponent znaczeniowy 'duchowny unicki', stał się w polszczyźnie ogólnej egzotyzmem językowym, episkop przeszedł do kategorii archaizmów, a powszechnie używany wyraz biskup, w swoim podstawowym znaczeniu 'duchowny obrządku łacińskiego', otrzymał dodatkowe określenia ruski, grecki, przez co zaczął nazywać także 'duchownego obrządku prawosławnego i grekokatolickiego'” (s. 204). 
Kolejny artykuł (P. Krzyżanowski, Rzeczowniki nieodmienne wobec normy gramatycznej wspótczesnej polszczyzny) poświęcony jest wyrażeniom, których nieodmienność jest zabiegiem wyróżniającym. Owa afleksyjność dotyczy według autora - 1) zapożyczeń (np. voodoo), 2) nazw własnych (np. Corleone), 3) żeńskich nazw zawodowych, tytułów i nazwisk kobiet (np. pani kierownik), 4) skrótowców (np. $P C K$ ). „Wyróżnieniu podlegają: nazwy obce - na tle rodzimych, nomina propria - na tle apelatywów i nazwy żeńskie - na tle gramatycznie męskich, które są tu eksponentami treści ogólnych (wykonawcy zawodu, nosiciele nazwiska, osoby obdarzone tytułem itp.). A więc nieodmienność, jak można by się tego spodziewać w języku fleksyjnym, charakteryzuje pewne stosunkowo niewielkie, szczególne grupy wyrażeń" (s. 213).

W. Książek-Bryłowa w artykule O zagadkach poetyckich w ,Ogrodzie, ale nie plewionym" Wactawa Potockiego przedstawia kilka utworów o charakterze ludycznym barokowego poety. Dzieli je (wzorem J. Kasjana i R. Tokarskiego) na opisowe i metaforyczne, odsłaniając mechanizm formułowania odpowiedzi. Artykuł kończy informacja, iż w twórczości poety odnaleźć można także tzw. mądre pytania o różne wartości. „Od zagadek różnią się tym, że nie wymagają one rozszyfrowywania tematu na podstawie parafrazy czy metafory, nie wymagają szukania związków między ukrytym obiektem a podanymi w parafrazie cechami, działaniami obiektu itp., ale są one probierzem mądrości zarówno nadawcy, który takie pytania formułuje, jak i adresata, który na te pytania odpowiada" (s. 224).

Celem artykułu M. Łesiowa zatytułowanego Systemowe zapożyczenia językowe $w$ środowisku dwujęzycznym jest ukazanie zmian w systemach polskiej i ukraińskiej gwary na obszarze bilingwalnym. Zmiany te - jak pisze autor - „zostały spowodowane zbliżeniem się wzajemnym obu systemów gwary potocznej, obu języków mówionych i może też ich form pisanych" (s. 228). Z przytoczonych przez badacza szczegółowych charakterystyk - głównie dotyczących fonetyki oraz fleksji - wynikły pewne uogólnienia, które sformułowano w czterech osobnych punktach.

W. Makarski w artykule Dąb jako baza staropolskich antroponimów dokonał przeglądu nazw osobowych z okresu staropolskiego, które dobrał według określonego klucza semantycznego. Dab jako element leksykalny stał się przedmiotem osobnych opracowań lingwistycznych, również toponomastycznych. Na potrzeby artykułu jednak autor ograniczył się do semantyczno-formalnej charakterystyki antroponimów. „Wyjątkowy status dębu w badanej staropolskiej antroponimii w porównaniu z innymi odarboralnymi mianami osobowymi objawia się w charakterystycznym typie złożeń egzocentrycznych Kazidąb, Porzydąb, Wyrwidąb wykorzystujących dąb jako symbol siły" (s. 247-248). 
Artykuł autorstwa J. Mazura nosi tytuł Szkolnictwo polskojęzyczne w Niemczech na tle językowej i edukacyjnej polityki Rady Europy. Jest opisem trudnej sytuacji szkolnictwa polskojęzycznego u naszych zachodnich sąsiadów. Uwidacznia się to donioślej w kontekście dokumentów Rady Europy oraz Traktatu polsko-niemieckiego z 1991 roku. Polityka językowa i edukacyjna zapisana w owych zaleceniach i rezolucjach wyklucza określone działania państw członkowskich, które jednak w odniesieniu do mniejszości polskiej w Niemczech nie są respektowane. Dlatego też autor postuluje realizację ośmiu założeń szczegółowych: „1. Należy stworzyć aktualną strategię rozwoju tego szkolnictwa, zawierającą rozwiązania systemowe [...]. 2. [...] należy myśleć o modelach wariantywnych, mających szansę wejścia w życie w określonej sytuacji lub dających możliwość jednoczesnego działania dwu-, trzykierunkowego. [...] 3. Odpowiednio do tego powinny być przygotowane programy [...]. 4. Koniecznie musi być wykorzystany Internet, tak w kształceniu językowym, jak i w doradztwie metodycznym oraz w innych aspektach działalności oświatowej. 5. Należy dążyć do podniesienia kwalifikacji nauczycieli i podwyższenia wymagań wobec nich [...]. 6. Koniecznie propagować zdobywanie przez jak największą liczbę osób, zwłaszcza nauczycieli, certyfikatu znajomości języka polskiego. 7. Warunkiem powodzenia jest zgodna współpraca poszczególnych organizacji polonijnych w Niemczech dla dobra oświaty polonijnej i polskojęzycznej. 8. Konieczne jest również stanowcze i aktywne włączanie się przedstawicieli władz polskich najwyższego szczebla w rozwiązywanie problemów oświaty polskojęzycznej w Niemczech" (s. 256-257).

Kolejny artykuł w tomie - utrzymany w tonacji wspomnieniowej - nosi tytuł Działalność lubelskich lektorów języka polskiego $w$ węgierskim Debreczynie. Na 65. urodziny Profesora Czesława Kosyla. I. D. Molnár dokumentuje w nim wieloletnią współpracę lektorów języka polskiego na Uniwersytecie w Debreczynie, na Węgrzech. Przypomina, że również Czesław Kosyl „podjął się pracy lektora języka na osobistą prośbę piszącego te zdania w czasie, kiedy kończył pisanie swojej dysertacji habilitacyjnej (Forma i funkcja nazw własnych). Została ona wydana w następnym roku, a obroniona w 1984 r. Debreczyńską działalność dydaktyczną ówczesnego docenta Kosyla najlepiej charakteryzują rzeczowniki: rzetelność, sumienność i humanitarność” (s. 260).

R. Mrózek w artykule Antroponimia przezwiskowa i determinanty jej funkcjonalności twierdzi, że istnieje potrzeba wprowadzenia terminu ,,antroponimy przezwiskowe" w odniesieniu do nazw osobowych motywowanych nazwiskiem lub imieniem. Takie rozwiązanie determinowane jest wyznacznikami socjologicznymi.

Tekst autorstwa S. Niebrzegowskiej-Bartmińskiej (Sakronimy w polskim ludowym obrazie ziół) to niezwykle ciekawa analiza nazw roślin, w których 
występują sakronimy. W języku polskim ich liczba jest niezbyt pokaźna i ograniczona do postaci Pana Jezusa (np. pantofelki Pana Jezusa), Matki Boskiej (np. Panny Maryi trawa), św. Jana (np. jagody czarne św. Jana) i św. Piotra (np. św. Piotra łysina). W szystkie tego typu rośliny ,posiadają niezwykle lecznicze właściwości, przywracają zdrowie, siły, czystość ciała, a oddalają chorobę, niemoc, nieczystość - to wszystko, co może być kojarzone z działaniem sił wrogich człowiekowi, złych duchów i demonów oraz złych ludzi, co zatem jest zaprzeczeniem sfery sacrum" (s. 286).

P. Nowak w artykule Snuje i grzatki. O poszukiwaniu nowych nazw dla piosenki $w$ mass mediach dokonuje analizy pola semantycznego leksemu piosenka. Przedstawia wyrazy o zasięgu ogólnopolskim i utworzone - z zachowaniem przejrzystości semantycznej - wyłącznie z rodzimego zasobu gramatycznego i leksykalnego. Autor omawia następujące określenia: utwór muzyczny, kawałek, ballada, przytulango, pościelówa, nudziarstwo, grzałka oraz snuj. „Na przykładzie snuja widać, jak trudno zastapić w języku potocznym słowo o bardzo szerokim zakresie, jakim stała się w ostatnich dziesięcioleciach piosenka, ponieważ każde nowe określenie jest albo używane na ograniczonym terytorium, jedynie w określonym środowisku, albo nie ma precyzyjnego i jasnego znaczenia, co z jednej strony uatrakcyjnia komunikację, a z drugiej prowadzi do braku precyzji i nieporozumień komunikacyjnych" (s. 298).

Artykuł A. Pajdzińskiej zatytułowany Antroponimy w poezji Wisławy Szymborskiej jest wstępną analizą nazw własnych wyekscerpowanych z utworów poetki. Autorka artykułu ogranicza się do badań antroponimii, stwierdzając, że w utworach współwystępują nazwy osobowe używane do nominacji osób autentycznych, rzeczywistych oraz fikcyjne - najczęściej zapożyczone z mitologii, literatury, folkloru. Noblistka, prowadząc nieustanną grę z odbiorcami, używa wielu nazw, które wymagają specjalistycznej wiedzy. Stąd rolą projektowanego czytelnika jest lektura nie tylko bierna, ale i czynna, która zakłada orientację w skomplikowanych strukturach tekstu poetyckiego.

Kolejny artykuł - Onomastyka w słowniku gwarowym autorstwa H. Pelcowej - to drobny szkic poświęcony problemowi wielokrotnie już podnoszonemu na gruncie onomastycznym. Autorka konstatuje - powołując się na ustalenia Ewy Rzetelskiej-Feleszko - że należy wyraźnie rozgraniczyć zasoby leksykograficzne słowników onomastycznych i gwarowych. Właściwe sprecyzowanie zasad doboru materiału jest niezbędne w odniesieniu do kategorii znaczeniowych, w których „mieszczą się określenia niebędące nazwami własnymi, chociaż mające takie właściwości [...]. Sumując, opowiadamy się za wąskim włączeniem onomastyki do słownika gwarowego" (s. 319).

D. Piekarczyk w artykule Tekst $w$ świetle metatekstu przedmiotem swego zainteresowania czyni wypowiedzi metatekstowe, do których opisu zastoso- 
wała metaforę TEKST JAKO DROGA. Przytoczone przykłady autorka dopasowała do cech tekstu, które eksponuje owa przenośnia. „Do ewokowania i podkreślania cech tekstu służy bowiem wiele różnych cech domeny wyjściowej, np. linearny układ punktów wyznaczających drogę, osoby poruszające się po drodze, możliwość poruszania się w obu kierunkach (w przód i w tył), istnienie dróg bocznych i przestrzeni wokół drogi, sposób poruszania się (spacer, jazda środkiem lokomocji), tempo i sposób ruchu, istnienie przeszkód na drodze, cele przemierzania drogi, długość trasy” (s. 323).

Tekst autorstwa M. Rutkowskiego (,Metaforyczne użycie nazw własnych” $w$ świetle niektórych założeń lingwistyki kognitywnej) to propozycja nowego odczytania procesu metaforyzacji onimów. Klasyczny zarys konstruowania metafory nazewniczej autorstwa Czesława Kosyla został uzupełniony (w świetle kognitywnych ustaleń metodologicznych) teorią stopów pojęciowych (amalgamatów), która steruje ludzkim myśleniem i ,umożliwia wskazanie całego szeregu konceptualnie relewantnych odpowiedniości między «przestrzeniami wejściowymi» (tu: denotatami nazwy) w zastępstwie opisowo sformułowanej, z konieczności ogólnej wartości konotacyjnej” (s. 340).

$\mathrm{W}$ artykule zatytułowanym Toposy $i$ tematy imienne $w$ perspektywie onomastyki literackiej I. Sarnowska-Giefing podkreśla istotność rozgraniczenia w badaniach onomastyczno-literackich dwóch terminów: topos (nazwa konwencjonalna) oraz temat imienny. Autorka twierdzi, że chociaż ich zakresy znaczeniowe należą do zbiorów przecinających się, to nie są one tożsame.

Artykuł A. Siwca zatytułowany Sposoby nominacji językowej w nazwach lubelskich firm to drobiazgowa analiza nazewnictwa firmowego. Z lubelskiego korpusu nazw autor wyodrębnił dwie grupy instytucjonalizmów. Pierwszą tworzą nazwy o motywacji translokacyjnej, drugą - mające motywację morfologiczną. Badacz na marginesie głównych rozważań dodaje ponadto konstatację, iż ,we współczesnym nazewnictwie handlowym zaznacza się bardzo mocno tendencja do tego, aby każda firma miała swoją własną niepowtarzalną nazwę i tym samym nie była anonimowa dla potencjalnych klientów. Jest to korzystne ze względów marketingowych, ponieważ nazwa własna pozwala firmie wyróżnić się z tła i może być lepiej niż szablonowy opis wykorzystana w reklamie i promocji” (s. 358).

Kolejnym tekstem w recenzowanym tomie jest artykuł K. Skowronek $N a$ zwy współczesnych polskich partii i organizacji politycznych jako językowe konstrukcje ideologiczne. Autorka poddaje wszechstronnej analizie nazwy polskich partii politycznych. Rozważania umieszcza w kontekście różnych publicznych i politycznych dyskursów, które wytwarzają socjonimy i wśród których one jednocześnie funkcjonują. W artykule stara się ponadto określić, w jakim stopniu czynniki ekstralingwistyczne determinują semantykę nazw 
organizacji partyjnych. „Struktura gramatyczno-leksykalna nazw partii i organizacji politycznych nie tworzy wyrazistego modelu czy jednego wzorca: raczej panuje $\mathrm{w}$ tej mierze pewien pluralizm, odpowiadający poniekąd pluralizmowi politycznemu i światopoglądowemu, jak też i zmiennym potrzebom rynku [...]. Brak stabilizacji w tym obszarze odzwierciedla wysoką niestabilność systemu politycznego" (s. 381).

T. Skubalanka w artykule Na marginesie wiersza Czestawa Miłosza z cyklu „Pamiętnik naturalisty” zaproponowała hermeneutyczną analizę wiersza noblisty. Pozwoliło to odkryć w tekście poety trzy główne konwencje narracyjne: baśniową, alegoryczną i realną. „Tak więc analiza [...] pozwoliła [...] odkryć w tekście poety splot różnorodnych znaczeń, które ukrywają się pod maską pozornej zrozumiałości” (s. 387).

Artykuł autorstwa R. Szczygła nosi tytuł Rozwój sieci osadniczej nad Łada od późnego średniowiecza do XVIII wieku. Badacz zauważa, że „pograniczne położenie badanego terytorium sprawiło, że procesy osadnicze zachodziły tutaj wolniej niż w pozostałych częściach ziemi” (s. 396). W artykule wskazano też na różną dynamikę procesów osiedleńczych - warunkowaną położeniem topograficznym oraz geopolitycznym.

Tekst autorstwa R. Tokarskiego - O czym się śni...? Względność kategorii aksjologicznych - wpisuje się w nurt badań aksjologii lingwistycznej. Autor dokonał analizy wiersza Jeremiego Przybory Już czas na sen. Utwór składa się z trzech części, „dedykowanych kolejno mężczyźnie, kobiecie oraz ojczyźnie. Ta ostatnia część faktycznie - poprzez przesunięcie metonimiczne - adresowana jest do Polaków. W każdej z części kreowany jest obraz hipotetycznego marzenia sennego, mającego w zamierzeniu pokazać świat preferowanych przez kolejnych adresatów wartości” (s. 401).

W artykule Jeszcze o funkcjach przykładów użycia jednostek leksykalnych $w$ stownikach $\mathrm{B}$. Walczak przeprowadza polemikę z uwagami Mirosława Bańki dotyczącymi funkcji użycia przekładów w dziełach leksykograficznych. Oprócz dwóch podstawowych: filologiczno-dokumentacyjnej oraz ilustracyjno-interpretacyjnej funkcji przykładów Bańko sugeruje wyodrębnienie funkcji egzemplifikacyjnej, z czym nie zgadza się Walczak: „Nietrudno zauważyć, że funkcja egzemplifikacyjna przykładu to pleonazm” (s. 411). W dalszej części tekstu poznański badacz broni zasadnego umieszczania w słownikach przykładów preparowanych, ale docenia też wagę gotowych korpusów tekstowych w pracy leksykografa.

Celem artykułu H. Wiśniewskiej zatytułowanego Nazwiska odapelatywne w średniowiecznych księgach Przemyśla (1402-1452) jest onomastyczna analiza antroponimów wyekscerpowanych z przemyskich ksiag miejskich. Onimy odapelatywne badaczka sklasyfikowała pod względem semantycznym. 
Autorka zauważa ponadto, że materiał onimiczny ,świetnie przechowuje stare leksemy i stare znaczenia, dowodzące naszej wiekowej sprawności językowej i kultury materialnej [...]" (s. 424).

Ostatni artykuł w tomie - autorstwa M. Wojtak - nosi tytuł Gwara jako tworzywo wypowiedzi prasowych. Autorka dokonuje opisu sposobów wyzyskiwania gwary do konstruowania tekstów medialnych. Przeprowadzone analizy wskazują, że język mieszkańców wsi to bardzo plastyczne tworzywo wykorzystywane do pisania, ,gdy trzeba przedstawić wiejskie realia, a zwłaszcza zanikające obyczaje czy różne składniki kultury materialnej określonego regionu oraz przeobrażenia kultury ludowej, związane z cywilizacyjnym uwikłaniem współczesnej polskiej wsi. Pośrednio tak używana gwara staje się indeksem stylistycznym [...]" (s. 439).

Recenzowany tom stanowi zbiór niezwykle ciekawych tekstów o zróżnicowanej tematyce. Autorzy poruszają kwestie aktualne we współczesnej polszczyźnie, a także typowe dla epok dawniejszych, co tłumaczy charakter dokonujących się zmian.

O wartości książki stanowią - moim zdaniem - gruntowność, precyzyjność oraz wielostronność przeprowadzonych opisów i analiz, a także bogactwo materiału. Interesujące są ponadto wyniki naukowych dociekań. Autorzy wykazali się znakomitą orientacją w literaturze przedmiotu, którą wyzyskiwali stosownie do swoich zamierzeń. Większość spostrzeżeń i uwag została przedstawiona w sposób przemyślany i uporządkowany, co sprawia, że publikację można będzie także wyzyskać w dydaktyce uniwersyteckiej. Oprócz solidnych podstaw materiałowych recenzowany zbiór studiów cechują również ciekawe tezy i wnioski oraz multimetodologiczne podejście do językoznawstwa. Dzięki tym właściwościom powstała książka bardzo wartościowa, bogata i różnorodna pod względem tematycznym, godna uwagi nie tylko językoznawców. Jest to publikacja godna polecenia. 